\title{
Description and Level of Difficulty in Learning Hematology for Medical Laboratory Technology (MLT) Students during One Year of the COVID-19 Pandemic
}

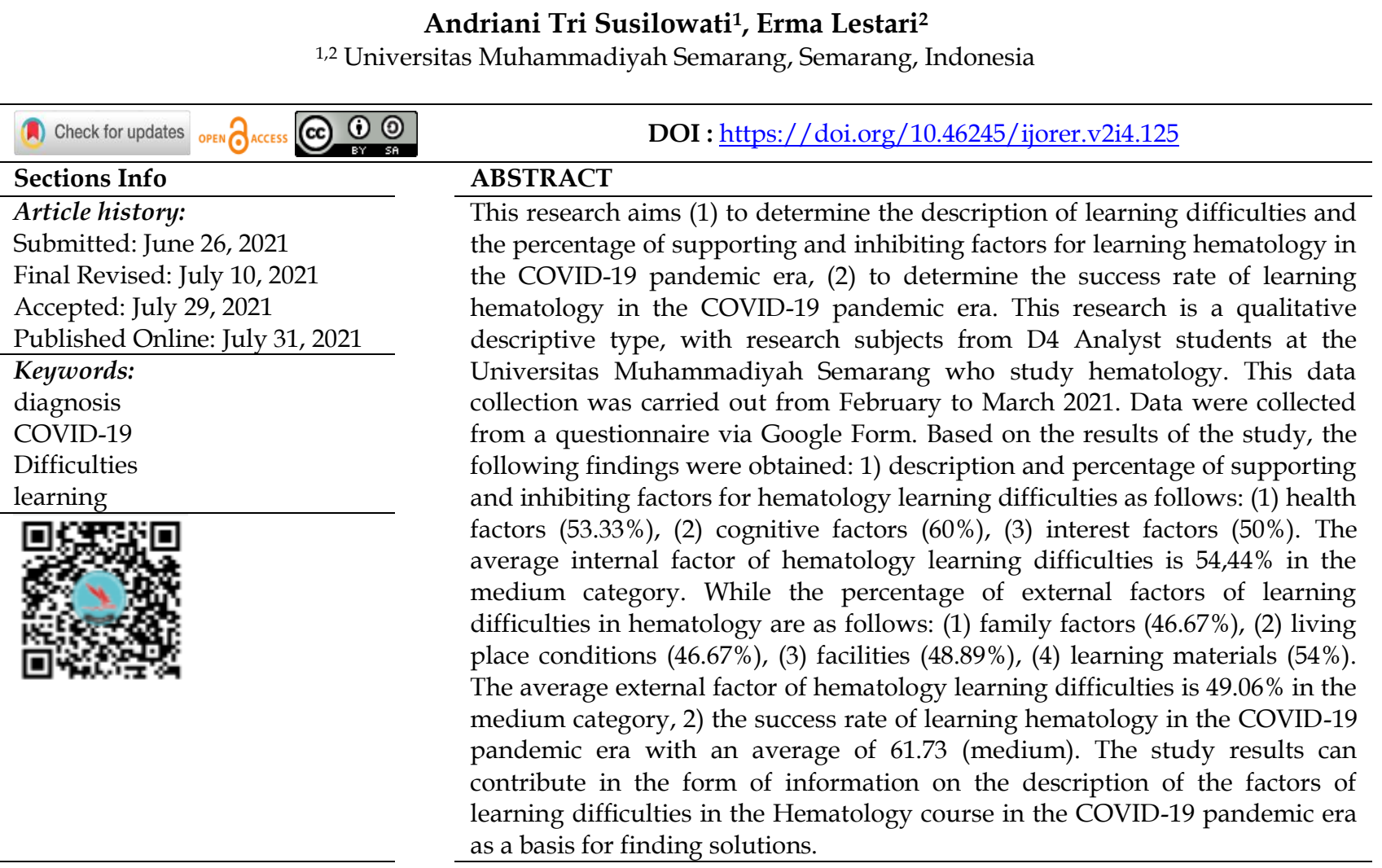

\section{INTRODUCTION}

Corona Virus Disease (COVID-19) is a new disease that attacks the human respiratory system caused by Severe Acute Respiratory Syndrome Coronavirus 2 (SARS-CoV-2). The nature of this virus is that it has a high-speed spread rate and attacks almost all countries globally, including Indonesia, in a short time. First discovered in Wuhan, China, on January 7, 2020, the Chinese government identified it as the Corona Virus. The first case in Indonesia was announced on March 2, 2020, and on March 11, 2020, the world health organization declared COVID-19 a pandemic/epidemic throughout the world (Kemenkes RI, 2020).

The speedy spread of COVID-19 and reaching almost all provinces in Indonesia with many cases and/or deaths led to Presidential Decree No. 11 of 2020 concerning Determination of Public Health Emergency (PHE). In tackling the PHE, the Government 
of Indonesia adopted a policy, namely Large-Scale Social Restrictions (PSBB), to suppress the spread of COVID-19 (Ministry of Health, Republic of Indonesia, 2020). The government forbids people from gathering. The people are advised to practice social and physical distancing, always wear masks and wash their hands. The Ministry of Education and Culture of the Government prohibits universities from conducting faceto-face (conventional) lectures and orders them to hold lectures online. Online learning is a way of learning using the internet network in access, connection, flexibility, and various learning interactions (Sadikin and Hamidah, 2020).

These changes certainly provide challenges for higher education managers in the implementation of learning. The primary key to successful online learning is effectiveness. Online learning can be effective if the technology, teacher characteristics, and student characteristics are good (Pangondian et al, 2019). There are many obstacles in the implementation of online learning during the COVID-19 pandemic. Facilities and smooth internet access are the biggest obstacles in the implementation of online learning. Internet networks that have not reached remote rural areas, unstable internet networks, and limited quotas are the main obstacles (Surahman et al, 2020). The larger the document or the type of media used, the larger the internet quota; this impacts the costs and progress of learning. Students who live in remote villages with poor internet networks experience obstacles in online learning activities. Online learning is hard to understand if using a simple method like PowerPoint. Learning using direct methods such as video conferencing such as Zoom, Webex, Google Meet, and the like also creates obstacles and burdens students in areas/rural areas with poor internet networks. Discussions cannot be carried out as well as face-to-face learning.

The piled-up assignments are also a problem for students. According to the schedule, students find it difficult to participate in learning activities, making them tired and not focused on assignments (Ernawati, 2020). Utomo et al (2021) showed that students experienced learning difficulties during the COVID-19 pandemic, which made students less understand the subject matter presented by the teacher. Simanjuntak et al. (2020) showed that out of 30 students, an average of 68.83 had learning difficulties, and the internet network was not smooth. Putri and Marpaung (2018) stated that the level of student learning difficulties results from $43.60 \%$. Utami et al, (2020) concluded in their research that the average student achievement regarding e-learning math learning difficulties was $75 \%$, with the lowest student achievement score in the implementation of interactions, assignments, and teaching materials in online learning by $73 \%$, and the highest achieved by students is on signal technical problems and inability to learn online (e-learning) which is $77 \%$. Rosal (2020) stated that the obstacles faced by students and lecturers in online learning include the availability of internet quota, unstable networks, and supporting tools such as gadgets and laptops. Wahyuningsih (2021) showed the problems of students in the form of inactivity in participating in learning and the limitations of supporting facilities and internet network access. Meanwhile stated that the negative impact was that students had technical difficulties in learning due to online lectures. 
Hematology is a material that requires more attention because it is a competency standard for D4 Medical Laboratory Technology (MLT) students. Hematology courses are not only theoretical but also require special skills that are used when working in a health care facility laboratory. For this reason, practical work is needed in the laboratory and cannot be replaced with teaching aids. This study aims to see the description and level of difficulty in learning hematology for D4 Medical Laboratory Technology (MLT) students during the one year of the COVID-19 pandemic and the possible solutions.

\section{RESEARCH METHOD}

\section{Research Type}

This research is a qualitative descriptive study. According to Sukmadinata (2016), qualitative research aims to describe and analyze phenomena, events, social activities, attitudes, beliefs, perceptions, and thoughts of people individually and in groups. Meanwhile, according to Sugiyono (2016), qualitative research methods are research methods used to examine the condition of natural objects, where the researcher is the key instrument, and data collection techniques are carried out by triangulation, data analysis is qualitative, and the results of the research emphasize meaning rather than generalization.

\section{Research Subject}

The research subjects were 212 students of D4 Medical Laboratory Technology (D4 Health Analyst) Universitas Muhammadiyah Semarang who studied Hematology course material. Data collection was carried out in March 2021.

\section{Data Collection Method}

Data was collected from a questionnaire via Google Form. Respondents were given a link and asked to answer questions on the Google Form. The questions in the questionnaire are negative and closed questions using a Likert Scale. The scores on this scale are: (1) never, (2) rarely, (3) sometimes, (4) often, and (5) always.

\section{Data Analysis Method}

The level of difficulty is assessed from total scores/total maximum score $\times 100 \%$. The data were categorized as $0-20 \%$ (very easy), $21-40 \%$ (easy); $41-60 \%$ (medium), $61-80 \%$ (difficult) and $81-100 \%$ (very difficult). Open-ended questions are provided to answer possible solutions according to research subjects.

\section{RESULTS AND DISCUSSION}

Based on the research results, the majority of students live in rural areas (64.2\%). Around $32.1 \%$ live in urban areas, and a small proportion lives in remote/border areas. As many as $55.2 \%$ of students use a cellphone to learn, while the remaining $44.8 \%$ use laptop. Most (93.8\%) lecturers use the Zoom learning application. 

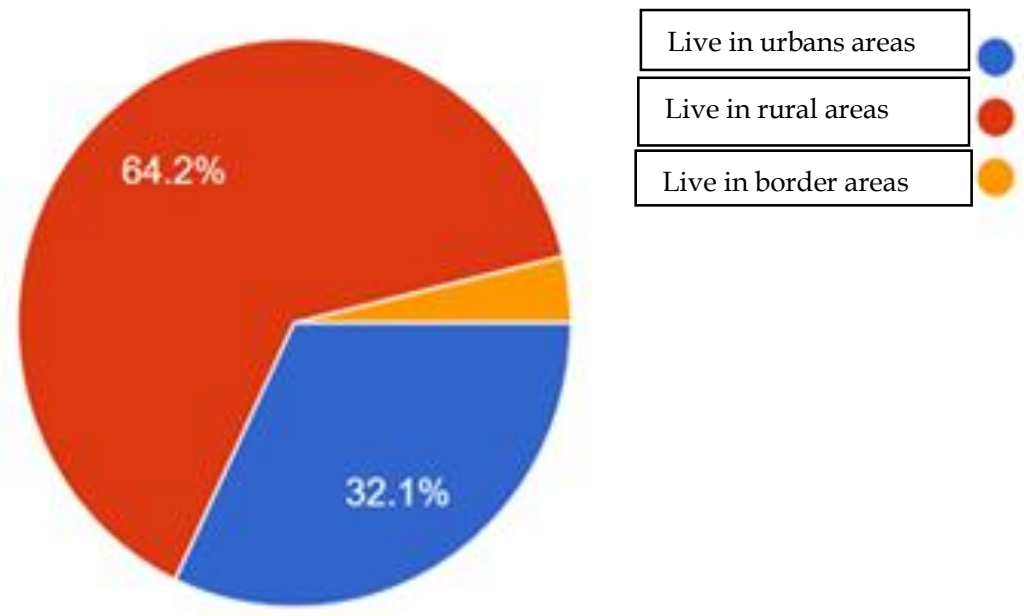

Figure 1. Diagram of residence.
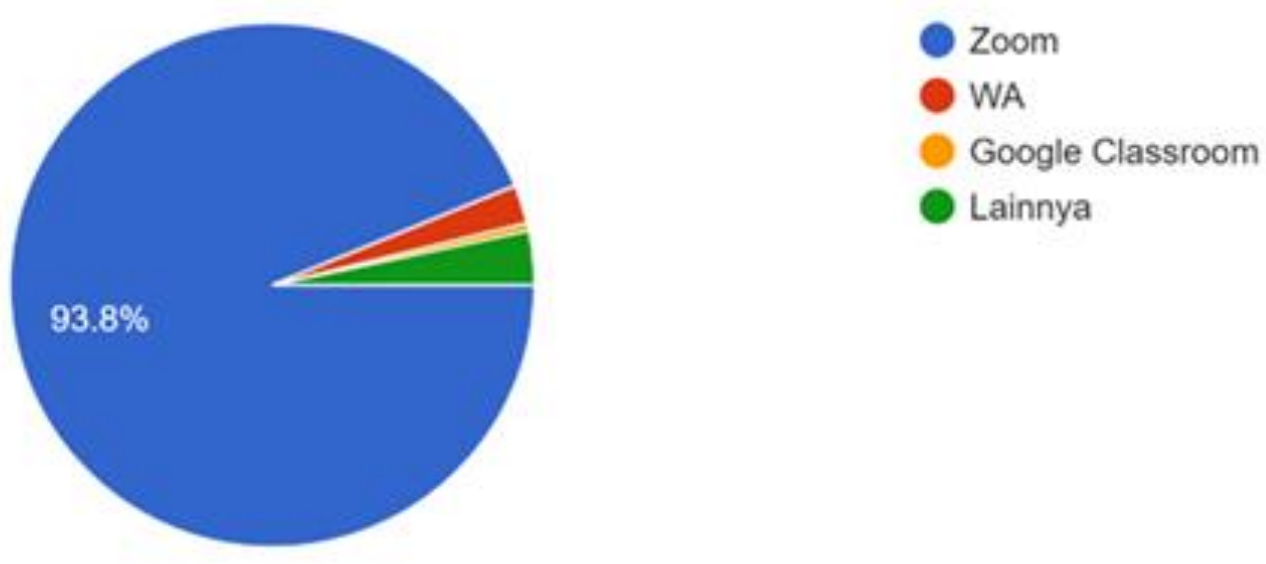

Figure 2. Diagram of hematology learning application.

Table 1. Percentage of internal factors of hematology learning difficulties.

\begin{tabular}{clccc}
\hline Indicator & \multicolumn{1}{c}{ Sub Indicator } & $\mathbf{( \% )}$ & Score & $\begin{array}{c}\text { Level of } \\
\text { Difficulty }\end{array}$ \\
\hline \multirow{5}{*}{ Health } & History of frequent illness during & 42,9 & 2 & \\
& the pandemic & 36,8 & 3 & \\
& Frequency of eating 1-2 times & 42,9 & 1 & $16 / 30 \times$ \\
& Food quality is not nutritious & 39,6 & 3 & $100 \%$ \\
& Often feel tired & 41,2 & 4 & \\
& Feel sleepy quickly & 47,2 & 3 & \\
& Lazy to work & & 16 & $53,33 \%$ \\
\hline
\end{tabular}




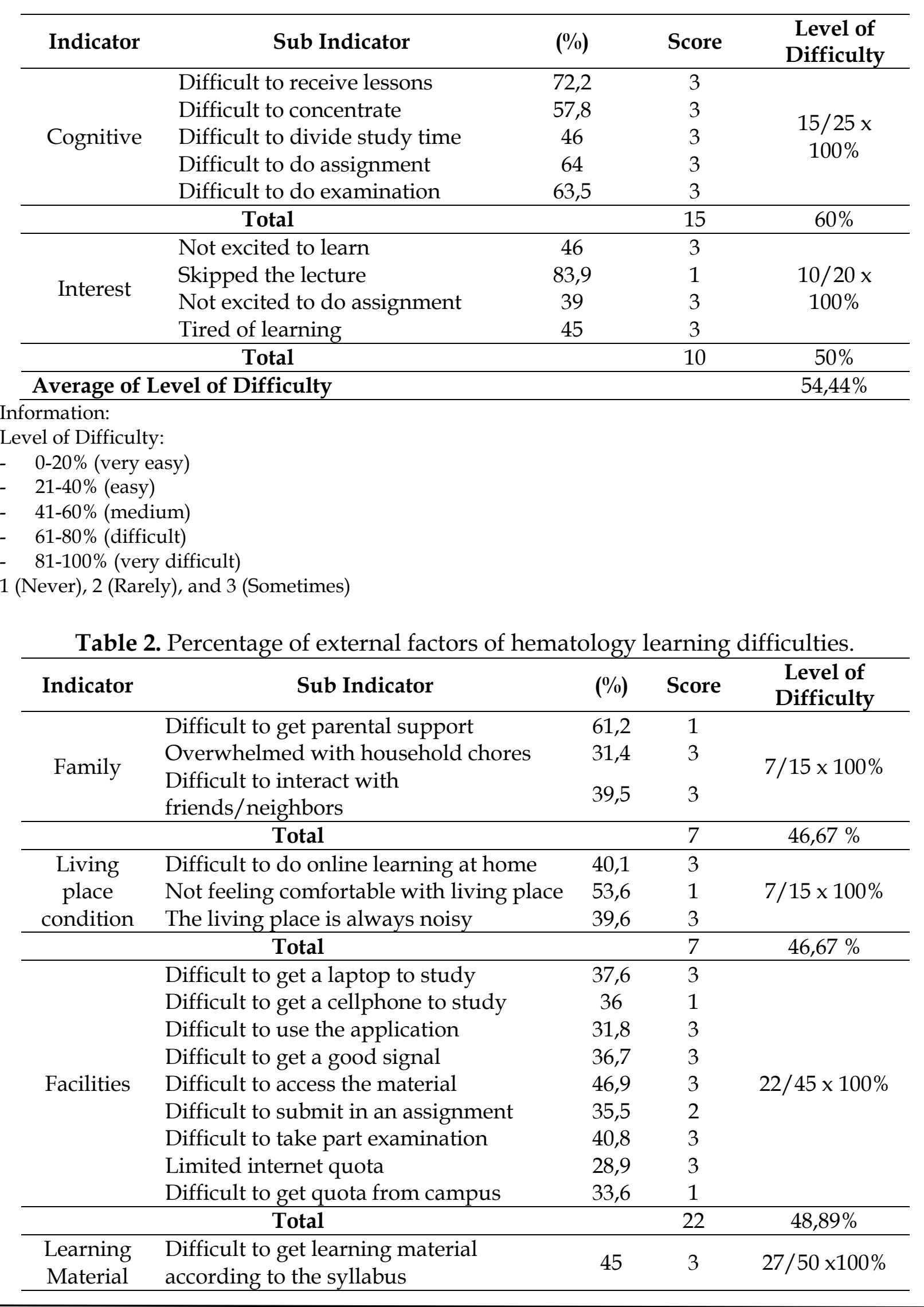




\begin{tabular}{|c|c|c|c|c|}
\hline Indicator & Sub Indicator & $(\%)$ & Score & $\begin{array}{l}\text { Level of } \\
\text { Difficulty }\end{array}$ \\
\hline & $\begin{array}{l}\text { Difficult to get a face-to-face meeting } \\
\text { (Zoom) }\end{array}$ & 44,5 & 3 & \\
\hline & Unclear material delivery & 56,1 & 3 & \\
\hline & Difficult to learn interactively & 46,7 & 3 & \\
\hline & Assignment of each meeting & 47,9 & 3 & \\
\hline & $\begin{array}{l}\text { Difficult to get lectures according to } \\
\text { schedule }\end{array}$ & 46,2 & 3 & \\
\hline & Difficult to get practicum schedule & 26,1 & 1 & \\
\hline & Difficult to follow practicum & 38,8 & 3 & \\
\hline & Poor practicum material delivery & 38,2 & 2 & \\
\hline & Difficult to get practicum skills & 36,4 & 3 & \\
\hline & Total & & 27 & $54 \%$ \\
\hline \multicolumn{2}{|c|}{ Average of Level of Difficulty } & & & $49,06 \%$ \\
\hline \multicolumn{5}{|c|}{ formation: } \\
\hline \multicolumn{5}{|c|}{ vel of Difficulty: } \\
\hline \multicolumn{5}{|c|}{$0-20 \%$ (very easy) } \\
\hline \multicolumn{5}{|c|}{$21-40 \%$ (easy) } \\
\hline \multicolumn{5}{|c|}{$41-60 \%$ (medium) } \\
\hline \multicolumn{5}{|c|}{$61-80 \%$ (difficult) } \\
\hline \multicolumn{5}{|c|}{$81-100 \%$ (very difficult) } \\
\hline Jever), 2 (Rar & ly), and 3 (Sometimes) & & & \\
\hline
\end{tabular}

Table 3. Percentage of hematology learning difficulties.

\begin{tabular}{cc}
\hline Factor & The Average Percentage of Learning Difficulties Level \\
\hline Internal & $54,44 \%$ \\
External & $49,06 \%$ \\
Total & $51,75 \%$ \\
\hline
\end{tabular}

Information:

Level of Difficulty:

- $\quad 0-20 \%$ (very easy)

- $\quad 21-40 \%$ (easy)

- $\quad 41-60 \%$ (medium)

- $\quad 61-80 \%$ (difficult)

- $\quad 81-100 \%$ (very difficult)

The success rate of hematology learning during the COVID-19 pandemic has an average achievement of 61.73. The details of the results are presented in Figure 3. 


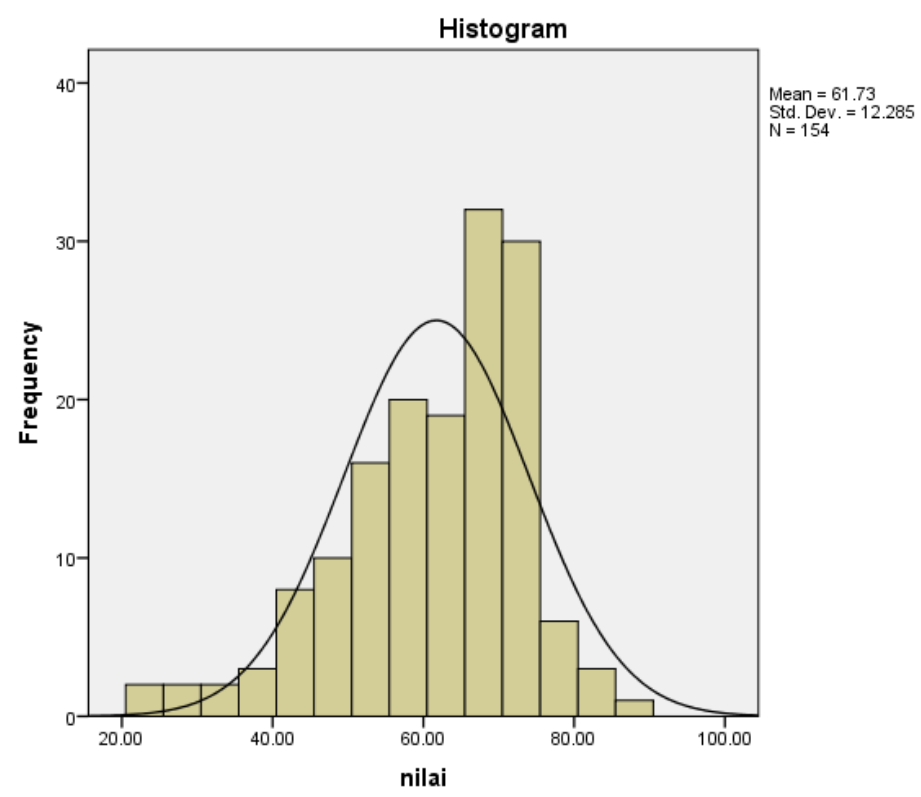

Figure 3. Histogram of the success rate of hematology learning.

The COVID-19 pandemic that has attacked more than 200 countries worldwide should not be a barrier to successful learning. Learning success is influenced by internal and external factors. Internal factors include physical and psychological conditions (talent and level of intelligence). In contrast, external factors include physical aspects (conditions of learning places, infrastructure, learning equipment, subject matter, and learning and social, environmental conditions) and social aspects (social support and cultural influences). Learning achievement includes cognitive, affective, and psychomotor aspects (Syarifuddin, 2011). The research results by Miftakhurrohman and Suyadi (2020) show that the impact of online learning makes students feel uneasy, ranging from not understanding the application to the system being implemented. As for the influence of mental pressure from the coronavirus, which of course, makes not a few students feel stressed.

The COVID-19 pandemic has lasted more than a year and has shifted from conventional learning to distance learning to prevent crowds and virus transmission. This change becomes a challenge in the learning process. Online learning is the main choice, and various ways are taken to carry out this learning. The choice of sudden and simultaneous online learning cannot be separated from problems that may hinder learning success. Iskandar et al (2020) showed online learning media for nursing students using Whatsapp (50.7\%), Zoom (49.3\%), and Google Classroom (11.8\%). Changes in learning media certainly have an impact on students in using applications and absorbing material. $73.9 \%$ of students do not understand the type of learning media, and only $26.1 \%$ understand media use. Affective factors include feelings in following online lectures. $56.6 \%$ of students feel dissatisfied, and $43.4 \%$ feel happy. Cognitive aspects in the form of understanding the material presented. $37.1 \%$ of students admitted that they understood a little, $31.5 \%$ said they understood quite well, 
and $23.8 \%$ felt they understood the material presented. The lack of success in learning does not escape the obstacles faced. $39.9 \%$ of students are constrained by internet network/signal, and $37.8 \%$ due to limited internet quota. According to Putri et al. (2021), there are still many students who have difficulty learning via Whatsapp to solve the material problems of the three-variable linear equation system during the COVID19 pandemic.

The most dominant obstacle in learning during the COVID-19 pandemic came from external and internal factors. External factors are internet quota and implementation of practicum courses, while internal factors are students' lack of understanding of the material. In this study, 93.8\% used the Zoom application for learning media. Difficulties in learning hematology were found both internally and externally. The average level of internal learning difficulty is $54.44 \%$. It can be categorized that internally students are quite difficult in learning hematology. Internal factors include health, cognitive, and interests. During the study of hematology, 53.33\% of students experienced health problems (Table 1). $41.2 \%$ of students are often sleepy, sometimes feel tired, and lazy to do activities. $36.8 \%$ only eat $1-2$ times a day. $60 \%$ experience difficulties from the cognitive aspect, where sometimes it is difficult to receive lessons, concentrate, divide time, do assignments and exams. Only 50\% of students are interested and happy to receive online learning.

The level of learning difficulty of external factors is $49.06 \%$. Most of the difficulties in learning materials (54\%), namely the difficulty of getting face-to-face meetings, delivering material that is not clear, the class schedule are irregular, and the difficulty of participating in the practicum. Overall, the level of difficulty in learning hematology from both internal and external aspects is $51.75 \%$ (medium). The limitations of learning are also felt in courses that require a practicum. Saputro et al (2020) show the science practicum learning strategies implemented by lecturers: (1) $68.75 \%$ using a studentcentered approach, (2) 50\% using Problem-based Learning, (3) 31.25\% independent practicum, and (4) 31.25\% using media WhatsApp. The learning limitations come from signal factors and social media $(68.75 \%)$, and internet factors $(31.25 \%)$. According to Anugrahana (2020), only 50\% of students are fully actively involved in online learning. Utami et al (2020) said that in the online mathematics learning process, high school/MA students often experience problems related to internet signals so that the number of assignments becomes large (77\%) and makes it students difficult in doing math lessons (73\%). The case is confirmed by Pibriana and Ricoida (2017), that the use of the Internet influences student interest in learning. Subarkah and Salim (2021) stated that students face obstacles in accessing internet devices and quotas. According to Moore et al. (2011), online learning uses the internet network with accessibility, connectivity, flexibility, and the ability to bring up various learning interactions. It results in students becoming less interested in online learning because they cannot learn independently and do not understand online learning. $48.89 \%$ of students experienced difficulties in terms of facilities. Sometimes students have difficulty: (1) obtaining a laptop while studying $(37.6 \%)$; (2) operationalize the application (31.8\%); (3) get a good signal quality (36.7\%); (4) accessing lecture materials (46.9\%); (5) take the exam (40.8\%); and (6) limited internet 
quota (28.9\%). Meanwhile, according to Dwi et al. (2020), the ineffectiveness of online learning is due to the lack of facilities and infrastructure and the unpreparedness of technology education. Winarti (2021) said that the average student learning difficulty was $60.90 \%$. Fauzy and Nurfauziah (2021) showed that the common obstacles experienced by students during online learning are the dominance of an inadequate internet network and full cell phone memory. Janah (2020) showed several obstacles faced by students, teachers, and parents in teaching and learning activities in the era of the COVID-19 pandemic, including the addition of internet quota fees. Annur and Hermansyah (2020) show that students face several difficulties classified into technical difficulties and adaptation difficulties. According to Ririn and Hartika (2021), the most dominant factor influencing student learning difficulties during the COVID-19 pandemic is infrastructure. Kurniasari et al (2020) state that learning from home is effective at $60-79 \%$ in general.

Based on the results of interviews with Hutauruk et al. (2020) on six mathematics education students, the obstacles faced by students are still bare. From the study results, the majority of respondents participated in online learning using Google Classroom, Whatsapp Group, and Zoom media. The constraint is the slow internet network because most live in rural areas, so it is difficult to submit college assignments, and the network is disconnected when attending lecture streaming. Some students who live in urban areas are not constrained by the internet network but are constrained by power outages. The difficulty when using the application is submitting assignments in the form of videos, downloading teaching materials and assignments. Students do not have textbooks as usual. Teaching materials provided by lecturers may be incomplete, while books/teaching materials available on the internet are not free. Students also have difficulty discussing with lecturers and more difficulty understanding the subject matter with online lectures than face-to-face. There is a lack of opportunity to discuss directly due to limited features, quality of the internet network, and using the comments column or chat with text so that many contexts cannot be conveyed clearly. Some lecturers only give assignments in every lecture meeting without explaining the subject matter/topic so that students are required to study on their own. However, despite the difficulties in learning, they still have full support from their parents.

Based on an open questionnaire in this study, some respondents stated that they had difficulties learning to use the Zoom application because the signal and quota were inadequate so that during learning, they had difficulty joining Zoom or suddenly exited the application. Students feel that there has never been direct practicum learning, so they have not been able to get skills according to competence. The success rate of hematology learning during the COVID-19 pandemic in this study had an average of 61.73 (medium) with 154 students as respondents. These results follow Hidayat's (2010) research that there is a significant relationship between internet use and student academic scores.

Students' hope for hematology learning is that offline/conventional learning can immediately be carried out while continuing to apply health protocols, especially practicum materials, to get skills according to their competencies, lecture materials 
before the Zoom implementation, and unstable signals constrain time attendance dispensation.

\section{CONCLUSIONS}

The COVID-19 pandemic that has lasted more than a year has caused many problems in the study of hematology. There are difficulties in following the learning from internal and external aspects. Internal factors dominate more than external. The level of health, cognitive, and interest in online learning is low. The external factor is dominated by the difficulty of getting a stable internet network quality to participate in learning via Zoom. Besides that, there is no direct practicum, and the unclear delivery of learning materials adds to the level of learning difficulty and the level of success in the medium category. Off-line/direct learning and practicum while still applying health protocols is the biggest hope for students to get the right skills and competencies. This research can be used as the basis for future research to find online learning solutions.

\section{ACKNOWLEDGEMENTS}

This research is competitive grant research funded by Universitas Muhammadiyah Semarang. We want to thank the Rector, the Head of the Study Program, and the Institute for Research and Community Service, Universitas Muhammadiyah Semarang. ID agreement letter: 027/UNIMUS.L/PT/PJ.INT/2021.

\section{REFERENCES}

Annur. M. F., \& Hermansyah. (2020). Analisis kesulitan mahasiswa pendidikan matematika dalam pembelajaran daring pada masa pandemi covid-19. Paedagoria: Jurnal Kajian, Penelitian Dan Pengembangan Kependidikan, 11(2), 195-201.

Anugrahana. (2020). Menyatakan bahwa hambatan, solusi dan harapan: Pembelajaran daring selama masa pandemi covid-19 oleh guru sekolah dasar. Scholaria: Jurnal Pendidikan dan Kebudayaan, 10(3), 282-289. doi.org/10.24246/j.js.2020.v10.i3.p282289

Dwi, C. B., Amelia, A., Hasanah, U., Putra, M. A., \& Rahman, H. (2020). Analisis keefektifan pembelajaran online di masa pandemi covid-19. Mahaguru: Jurnal Pendidikan Guru Sekolah Dasar, 1(1), 28-37.

Utomo, K. D., Soegeng, A.Y., Purnamasari, I., \& Amaruddin, H. (2021). Pemecahan masalah kesulitan belajar siswa pada masa pandemi covid-19 kelas IV SD. Mimbar PGSD Undiksha, 9(1), 1-9. doi.org/10.23887/jjpgsd.v9i1.29923

Ernawati, Y. (2020). Problematika pembelajaran daring mata kuliah bahasa Indonesia. Jurnal Ilmiah Bina Edukasi. 13(1), 01-15. doi.org/10.33557/jedukasi.v13i1.1029

Fauzy, A., \& Nurfauziah, P.(2021). Kesulitan pembelajaran daring matematika pada masa pandemi covid-19 di SMP muslimin cililin. Jurnal Cendekia: Jurnal Pendidikan Matematika, 5(1), 551-561. doi.org/10.31004/cendekia.v5i1.514

Hidayat, R. (2010). Analisis tingkat penggunaan internet di kalangan mahasiswa dan hubungannya dalam peningkatan nilai akademik (studi kasus pada mahasiswa di kota medan). Jurnal Mediasi, 2(2), 55-63. 
Hutauruk, A., \& Sidabutar, R. (2020). Kendala pembelajaran daring selama masa pandemi di kalangan mahasiswa pendidikan matematika: Kajian kualiatatif deskriptif. Journal of Mathematics Education and Applied, 2(1), 4551. doi.org/10.36655/sepren.v2i1.364

Iskandar, Masthura, S., \& Oktaviyana, C. (2020). Penerapan sistem pembelajaran daring pada mahasiswa keperawatan universitas abulyatama. Jurnal Dedikasi Pendidikan, $4(2), 323-332$.

Janah, S. R. (2020). Hambatan belajar siswa pada masa pandemi covid-19 di ma ma'arif 06 pasir sakti lampung timur. As-Salam: Jurnal Studi Hukum Islam \& Pendidikan, 9(2), 225-240

Kementerian Kesehatan Republik Indonesia. (2020). Pedoman pencegahan dan pengendalian corona virus disease (covid-19) revisi kelima. Jakarta.

Kurniasari, A., Putro Pribowo, F. S., \& Putra, D. A. (2020). Analisis efektivitas pelaksanaan belajar dari rumah (bdr) selama pandemi covid-19. Jurnal Review Pendidikan: Jurnal Kajian Pendidikan Dan Hasil Penelitian, 6(3), 1-8. doi.org/10.26740/jrpd.v6n3.p246-253

Miftakhurrohman, M., \& Suyadi. (2020). Persepsi mahasiswa terhadap pembelajaran daring perspektif neurosains pendidikan islam. At-Ta'dib: Jurnal Ilmiah Prodi Pendidikan Agama Islam, 12(02), 127-137. doi.org/10.47498/tadib.v12i02.375

Moore, J. L., Dickson-Deane, C., \& Galyen, K. (2011). E-Learning, online learning, and distance learning environments: Are they the same?. Internet and Higher Education, 14(2), 129-135. doi.org/10.1016/j.iheduc.2010.10.001

Pangondian, R. A., Santosa, P. I., \& Nugroho, E. (2019). Faktor - faktor yang mempengaruhi kesuksesan pembelajaran daring dalam revolusi industri 4.0. Seminar Nasional Teknologi Komputer \& Sains (SAINTEKS), 122(1), 1-9.

Pibriana, D., \& Ricoida, D. I. (2017). Analisis pengaruh penggunaan internet terhadap minat belajar mahasiswa (studi kasus: perguruan tinggi di kota Palembang). Jatisi, 3(2): 10-115. doi.org/10.35957/jatisi.v3i2.72

Putri, M. D., \& Marpaung, J. (2018). Studi deskripsi tentang tingkat kesulitan belajar siswa kelas VIII di SMP negeri 50 Batam. Cahaya Pendidikan, 4(1), 34-43. doi.org/10.33373/chypend.v4i1.1280

Putri, U. C., Saragih, E. M., \& Astuti, D. (2021). Analisis kesulitan belajar via whatsapp siswa kelas X pada masa pandemi covid-19. Jurnal Matematics Paedagogic, 5(2), 137-144. doi.org/10.36294/jmp.vxix.xxx

Ririn, D., \& Hartika, D. (2021). Identifikasi kesulitan belajar mahasiswa pada mata kuliah statistika selama masa pandemi covid-19. Jurnal Ilmiah Universitas Batanghari Jambi, 21(1), 148-155. doi.org/10.33087/jiubj.v21i1.1236

Rosal, E. S. (2020). Aktifitas pembelajaran daring pada masa pandemi covid-19 di jurusan pendidikan geografi universitas siliwangi tasikmalaya geography. Science Education Journal (Geosee), 1(1), 21-30.

Sadikin, A., \& Hamidah, A. (2020). Pembelajaran daring di tengah wabah covid-19. Jurnal Ilmiah Pendidikan Biologi, 6(2), 214-224. doi.org/10.22437/bio.v6i2.9759 
Saputro, B., Saerozi, M., \& Ardhiansyah, F. (2020). Philosophical reflections: Critical analysis of learning strategies for science practicum during the covid 19 pandemic. IJORER: International Journal of Recent Educational Education, 1(2), 7889. doi.org/10.46245/ijorer.v1i2.26

Simanjuntak, D. R., Ritonga, M. N., \& Harahap, M. S. (2020). Analisis kesulitan belajar siswa melaksanakan pembelajaran secara daring selama masa pandemi covid 19. Jurnal MathEdu (Mathematic Education Journal), 3(3), 142-146.

Subarkah, M. A., \& Salim, A. (2021). Analisis kesulitan belajar peserta didik dalam pembelajaran jarak jauh (PJJ) di tengah pandemi covid-19. Rausyan Fikr: Jurnal Pemikiran \& Pencerahan, 17(1), 22-30. doi.org/10.31000/rf.v17i1.4184

Sugiyono. (2016). Metode penelitian kualitatif dan REDD. Bandung: Alfabeta.

Sukmadinata, N. S. (2016). Metode penelitian pendidikan. Bandung: PT Remaja Rosdakarya.

Surahman, E., Santaria, R., \& Setiawan, E. I. (2020). Tantangan pembelajaran daring di Indonesia. Journal of Islamic Education Management, 5(2), 89-98. doi.org/10.24256/kelola.v5i2.1397

Syarifuddin, A. (2011). Penerapan model pembelajaran kooperatif belajar dan faktorfaktor yang mempengaruhinya. TA'DIB, 16(1), 113-136. doi.org/10.19109/td.v16i01.57

Utami, Y. P., Alan, D., \& Cahyono, D. (2020). Study at home: Analisis kesulitan pada proses pembelajaran daring. Jurnal Ilmiah Matematika Realistik (JI-MR), 1(1), 20-26. doi.org/10.33365/ji-mr.v1i1.252

Wahyuningsih, S. K. (2021). Problematika pembelajaran daring di masa pandemi covid19 di SMA Dharma Praja Denpasar. Jurnal Pangkaja, (24)1, 107-118.

Winarti, P. (2021). Analisis kesulitan belajar mahasiswa dalam perkuliahan konsep dasar IPA fisika secara daring di masa pandemi covid-19. Jurnal Komunikasi Pendidikan, 5(1), 93-107. doi.org/10.32585/jkp.v5i1.1076

\footnotetext{
* dr. Andriani Tri Susilowati, Sp.PK, M.Sc. (Corresponding Author)

Universitas Muhammadiyah Semarang,

Jl. Kedungmundu Raya No. 18 Semarang, Jawa Tengah, Indonesia

Email: andriani@unimus.ac.id

dr. Erma Lestari, Sp.PK

Universitas Muhammadiyah Semarang,

J1. Kedungmundu Raya No. 18 Semarang, Jawa Tengah, Indonesia

Email: ermalestari@gmail.com
} 